\title{
Memories, Lives, Lost Psycho-Sociologies from the Past and Human Behavior of Albanians in the Epoch of Capital
}

\author{
Nevila Koçollari ( Furxhiu), Ph.D. \\ University of Tirana, Social Sciences Faculty \\ Department of Policies and Social Work \\ nkocollari@gmail.com
}

\section{Doi:10.5901/ajis.2013.v2n9p566}

\begin{abstract}
The paper will present parts of "forgetful" social and psychological experiences between two periods: the socialist and the postsocialist one, to indicate likeness, dilemmas about missed values and necessities in special groups of population in Albania. It'll be a qualitative study, based on semi-structured interviews and specific cases that include real and special experiences, official documents, cinematography, etc. The period after 1990 based totally on the different civil background, has brought other concepts for democracy, solidarity, public participation and surely oneself and others confines concepts. The two world generations human behaviors dilemma, is the strongest barrier for Albanian culture values. The results will tell us if there is attention and appreciation about the past among the Albanians, how they understand it now, in big vigor of localization, globalization epoch and the desire to enter in Europe.
\end{abstract}

Keywords: solidarity, tradition, "new man", owner, collective behavior.

\section{Introduction}

Study based on qualitative analysis, is an attempt to show the physiognomy of nowadays perceptions about postcommunist Albanian society. Bringing out the values or strong points of the past regime, may affect the actual social policies as a credible base of welfare state, or may influence the revaluation of the social capital concept and practice, both important to achieve the European integration. The paper tents to describe the situation about the question chosen. Besides literature, observation, semi-structured interviews, special attention is paid to the reporting of story-telling by people of different generations and professions, in order to understand their lifestyle, their perception of culture, place and space, the perception of the themselves and the others under socialist regime and after it. Issues are seen in the light of social work, a profession that affects the awareness of the community about its values and processes of its growth, to better orient the opportunities according the development policies in the area through lobbying.

The post-1989 era was labeled "the end of history" (Fukuyama, 1992) ${ }^{1}$. While Lucio Magri²,a leading member of the Italian Rifondazione Communista, suggested:

When the Berlin Wall came down the judgment of many people was one of euphoria. They saw the coming of a anew historical period marked by word cooperation, democratic advance which would provide a clear opportunity for democratic socialism with a human face. Now we can see that the reality is different and much harsher (1991, p.5).

However, societies are at the same time being plunged into socially responsible the depths of their own histories. People should be guided in their evolution towards becoming citizens. Memories of socialism illicit anger and shame provoke laughter and derision; they activate feelings of rupture, trauma and loss, and conjure up images of injustice and victimhood. At the same time, more positively, they give those who remember a sense of victory, triumph, closure. As kind of social knowledge, those memories are not seeing only as strategies of "enrichment," but also as a resource for constructing cognitive frameworks where to anchor oneself existentially at a profoundly disorienting moment of transformation. In other words, we need to document and understand better not only what but also how people reminisce.

${ }^{1}$ Fukuyama,F.(1992):The end of the history and the last man. New York: Free Press.

2 Magri,L.(1991): "The European Left between Crisis and Re foundation" New Left Review,189, ,pp.5-18 
To quote David Sutton (1998: 3)3, "the past comes in many different containers bearing different labels." Those multiple "containers" are often as significant as the mnemonic messages they carry". One of the key arguments holds that "nostalgic" icons are successful because they play the cultural role of mnemonic bridges to rather than tokens of longing for the failed communist past. This phenomenon has recently become an object of scholarly research, inducing Maria Todorova when write, paraphrasing Marx, that "a specter is haunting the world of academia: the study of post-Communist nostalgia" (Todorova and Gille 2010:1) ${ }^{4}$. Todorova argues that mainstream discourse treats nostalgia in the postcommunist world as a "malady", an anachronism, a dysfunctional attitude towards a "seductive" yet "deadly" ideology, according to moral philosopher Tzvetan Todorov. Because of the broken historical continuity, it is hard to put back together the pieces, to recompose the puzzle, since words have ceased to speak in an intelligible way.

I agree that memory as a practice and a generator of social knowledge (to remember is to know) affords a productive site in which to investigate and to better apprehend the ongoing post-socialist transformation with its many unintended and bewildering consequences. So we need to understand that memory's principal concern is the present. Anthropologist Rubie Watson (1994: 6) $)^{5}$ has written that "constructing the new is deeply embedded in reconstructing the old. Specifically with regard to post-socialist Eastern Europe, it seems that we construe the ongoing accumulation and possession of memories as a strategy for generating a kind of symbolic capital.

\section{Situation in Albania}

The last decade has been one of great political, economic and social transformation in Albania, representing one of the most notable and turbulent periods in the history of the country. Most of the changes were difficult to predict for Albanians, whose expectations of a better life at the outset of the transition from communism were enormous, characterized by a desire to become a country like the rest of Europe. Their expectations for the future were great, but the path to turning them into a reality was lined with much naive thinking. Democracy was identified with political pluralism, justice was thought of simply in terms of a reform of the legal system, a market economy was envisaged in terms of extreme liberalism and the privatization of almost everything, and economic development was viewed as unlimited external assistance and foreign investment. Of course, such a situation of great expectations existed in almost all the post-communist countries of Europe. What distinguished Albania from the other transition countries was that its point of departure was vastly different. It was the most isolated and poorest country on the continent with one of the highest percentages of rural population ${ }^{6}$.

The opening of Albanian society had made the life style and preferences of urban society (especially in Tirana) more uniform and European but, at the same time, the other part of society, rural society in particular, has returned to its traditional way of life: characterized by patriarchal families, the Kanun and blood-feuding, etc. Demographic developments together with major internal (rural to urban) migration, rural depopulation and social fragmentation, the effects of unchecked urbanization, increasing lack of social cohesion, all with long-term repercussions for the emancipation and civilization of society, have had troublesome effects both in the cities and in the countryside. Regional allegiances, held back by ideology during the communist period, have begun to resurface, exerting their influence both over political and government organization and over the country's economic and social development. The desire and willingness of people to respect the law is the one sphere in which Albanian society in transition has made the least progress. Yet, efforts to interest Albanian civil society in respecting the law by encouraging the willingness and social conscience of people to change their attitudes have proven largely unsuccessful.

The political arena in Albania has evolved substantially over the last decade. During the early stages of the transition, politicians were divided into self-declared "anti-communists" and those accused of being the "heirs of communism." This extreme ideological polarization, which rather superficially equated democracy with anti-communism, also had an impact on relations between the political parties and created a climate of extreme conflict in the country which, in turn, gave rise to tension and social destabilization. Over the last few years, politics have developed new characteristics. The high level of political militancy characteristic of the earliest years of transition has been replaced by a narrower militancy, and one, which is more, focused on self-serving interests. For example, if, in the early stages of the

\footnotetext{
${ }^{3}$ Sutton, D.(1998): Memories Cast in Stone: The Relevance of the Past in Everyday Life. Oxford: Berg.

${ }^{4}$ Todorova, M., Nikolaeva, and Zsuzsa Gille.(2010): Post-Communist Nostalgia. New York: Berghahn Books.

${ }^{5}$ Watson, R.( 1994): "Memory, History, and Opposition under State Socialism: An Introduction." in R. Watson (ed.) Memory, History, and Opposition under State Socialism. Santa Fe: School of American Research Press.

${ }^{6}$ Human Development Report, Albania 2002.
} 
transition, personnel changes in the administration were carried out with the idea or pretext of replacing the old class and bureaucracy, it is now access to government administration which motivates membership in political parties. The extreme polarization of the public has gradually been replaced by a certain reservation and even an indifference towards politics. Searching for clear and definite solutions, may be easy to find in particular ambivalence and divergence between honest work and corruption, between the institutionalization of the market-based and the informal sectors of the economy, between the well-being of families and illegal traffic in drugs and human beings, between the complete opening of as yet fragile and uncompetitive economy and domestic production, and between environmental protection and unchecked urbanization. Poverty as a multi-dimensional phenomenon has grown markedly in Albania and contrasts starkly with the obvious economic achievements of the last decade of transition. Whereas in the past, the widespread state of poverty was not officially recognized, the Albanians now suffer from a measurable increase in income poverty and from a rapid polarization of society reflective of increasing economic and social disparities. The indicators of unemployment have features which reflect not only rhythms of change, but also traditions, characteristics and opportunities for development in the various regions. Some old traditions, supported by the stipulations of the Kanun, began to make their presence felt in the countryside, in particular in the northeast of the country. At the same time the government and society are still powerless or remain indifferent to these issues.

During the transition period, Albanian women were confronted with the revival of old phenomena of discrimination and of new phenomena which did not previously exist in Albania. When most of the state enterprises closed down in the initial stages of transition, women were among the first to lose their jobs, and finding a new job became quite a difficult challenge for them. The trafficking of girls and women for prostitution has also become a serious problem in Albanian society until some years ago. Compared to several other Balkan countries, Albania has shown the lowest level of human development ${ }^{7}$. This result is complex to analyze. It has to do with a combination of historical, political, economic and social factors. The Albanian transition has been negatively affected by the long drawn-out crisis in the region, in particular the war in former Yugoslavia and especially the Kosovo crisis. Society has been changing rapidly during the transition period. Earlier norms, values and convictions have been shaken deeply and society is still having difficulty finding itself regard to ethic and moral. It is being faced with many dilemmas. People are in search of new symbols and institutions with which they can identify. Thus, the problem of relations between the individual and society has come increasingly to the fore. Under the dictatorship, individuals had their own way of thinking and speaking, and a system of common values set forth by official ideology. Under these conditions, collective freedom had priority over individual freedom. As such, communism was not able to educate the people to place an active role as citizens. The transition from collectivism to individual freedom for the population has been an urgent necessity, but it has also proven rather difficult. According to this new logic, there are a few individuals (foreigners and Albanians) who own the truth and who hold the key to the future. The media on its own have reinforced this type of thinking. It is a process "without a subject" in which the ruins of the old system and the dynamic of the new economic and political mechanisms coexist. This serves in part to explain the weaknesses of democratic institutions and the difficulties involved in activating them. This mentality reflects the universe of post-communist Albanian politics and has had a negative influence on the creation of responsible citizens working actively for the democratic welfare of the country. It also reflects the fact that political discourse tends to gravitate towards charisma, demagogy and personal loyalties. The old way of thinking inherited from dictatorship continues to survive, i.e. a polarization of politics between the "we" (the convinced supporters of the true political course) and the "they" (enemies of the people and of the Party). It continues despite the fact that the now less acute distinction is difficult to make. Cultural institutions, after years of isolation, had difficulty changing their way of thinking and adapting to the new logic of a market economy (now, surely the situation and people behavior has been changed). What unfortunately characterized cultural institutions for quite some time was confusion, which caused serious damage to the country's cultural heritage and activities. The mass migration of the village and mountain population to the towns and coastal plain together with the end to the extreme isolation and social immobility which lasted half a century and was characteristic of the communist period, caused a change in the whole system of values for many Albanians and set in movement a complex process of cultural and economic change.

\section{Socialist register}

Let's start with a methodological point. The first, due to the classical logic of the comparative approach, is to seek

\footnotetext{
${ }^{7}$ Human Development Report, Albania 2002
} 
uniformities and similarities in the sea of diversities and differences and then to account for the reasons why such uniformities emerge. The second, opposite in intention, unravels specificity and uniqueness in the sea of seeming homogeneity and then explains why such diversity emerges and persists (Sztompka, 1990) ${ }^{8}$. According to Cyril E. Black of Princeton University in his preface to Stavro Skëndi's book Balkan Studies (1987), "Albania encompasses within its mountainous frontiers the characteristic Balkan problems-but in an extreme form." ${ }^{9}$ In Albanian studies you can find almost nothing pure sociological according these standards and theoretical practices. Most of the effort in studies of transformation has so far been concentrated on gathering data, particularly by means of survey research, opinion polls, etc. In effect, the diagnosis of the process is very rich. But theoretical reflection has been much more limited. Paradoxically, if it exists at all, it came mostly from outsiders. Under socialism sociology should come close to history and economics as well Marks theory predicted. Strangely this was not the case. In those countries where it was officially recognized, sociology was placed somewhere between the brand of philosophy known as Marxism-Leninism or scientific communism, some forms of political reflection, and fact-oriented demographic statistics. Now the whole perspective on social change was revised: the belief in necessary was replaced by the image of "social becoming". Political science, economics, cultural analysis joined hands with sociology and a number of studies crossed the traditional disciplinary borders in many countries of East Europe, but not so much in Albania. Another issue we faced was the impact of globalization on Albanians life. In social sciences ideas, concepts, models, and theories characteristically flowed mainly between Europe and America.

\section{Findings}

Respecting the dynamic use of the term, the components of the memory in a community although not always carefully assessed are: environment (how it has been transformed by man), home, social relations of everyday life, traditions and customs, rituals, spoken language, music and songs, objects used, typical products, the body and the world vision. Speaking for Albania, as a post-communist country marginalized by the policies of the socialist ideology, the objective is not the protection of the past memories, not repeated at all, but the activating of the capacity to detect it as the essence of the changes. This can be valid not only in the economic and social perspective, but also in that of symbolic, because despite the fact that the process of modernization can't stop, it's necessary to stop the degradation processes of economic, social and cultural development.

A great impact to write this paper I had when I read about the work made by an Albanian artist Anri Sala (1998) ${ }^{10}$ where the filmmaker finds a mute footage of his young mother, giving an official speech during a communist youth meeting in Albania. He hires an expert to read her lips in the video in order to understand what she was saying, but her once meaningful and enthusiastic declarations now appear only as empty ideological slogans. Thirty years later, the filmmaker's mother is full of disbelief when she told that really articulated those words. By re-situating these words in past times, and by tracking contemporary forms of nostalgia, remembrance, amnesia and disbelief now, we can set free the changes in ways of speaking and of signifying, and thus the political and historical changes in gender regimes and in women's lives.

We found that memories in post-socialism, does not seem to follow strict sequential chronologies. While some pasts are retrieved and imbued with memorial significance, others are largely disvalued and forgotten. Some reminiscences are more privileged than others; still others have little or no memorial status at all. As well as with young and professionals, I talked to several people in their sixties and seventies who claimed they had no desire to travel back to "that place of crime" as one of them referred to the dictatorship state. Memory is constantly on our minds not because there is so little of it left, but precisely because there is so much of it. They told me about the main newspaper "Zëri $\mathrm{i}$ Popullit" ("Voice of the people"), where was often declared that all the generations in Albania should live and grow in a socialist country, the dictatorship of the proletariat. Today we have the same newspaper, but we don't find thing like that."

Fiona, Social Worker, 38 years old, told me that nostalgia for the existence of specifics form of welfare state is one of the most mentioned by her clients, especially among third generation in some urban area in Albania. She was not wrong at all, because one elderly woman, for instance, confided in me that her personal memory of "the good life" in

\footnotetext{
${ }^{8}$ Sztompka, Pitor (1990): "Conceptual Frameworks in Comparative Inquiry", in Globalization, Knowledge and Society, Albrow, M. and King, E. (eds.),London, Sage, 47-60.

${ }^{9}$ Skëndi,S.(1987):Balkan Studies, New York, Columbia University Press,4.

${ }^{10}$ The work Intervista- Finding the words (1998). Cited also in Bonfiglioli, Chiara, (2011): in Former East, Former West: post-Socialist Nostalgia and Feminist Genealogies in Today's Europe, www.formerwest.org.
} 
socialism was the only thing that sustained her in day-to-day existence as an impoverished pensioner after socialism. "I have been teacher and everybody respected me. Now I live by those memories only, because the money I get are not enough even for medicines. I feel nobody. All services were free of charge."

Burbuqe, near 50, with middle professional education at that time, for the moment out of job, declared:" Who said we didn't live well? Yes, not all the people, but I'm nostalgic of that time. Not only at school, but the friendship was pure and sincere. We were safe to pass the streets even in the midnight. We were all like brothers and sisters, working together and helping each -other."

Alketa, near 45, electronic engineer pedagogue at university remembered the time of "zbori", the military training at school and university. "Wearing that clothes, I've had always need to sleep-she said. We were not aware about the enemy, but we loved this period, because we were more near to each-other, boys and girls, it was a kind of informality that in my opinion, we wanted really to have. I remember also the "actions days" or "walking days", free of classes, where all have almost the same food: bread, butter (lucky to have), eggs and cheese... We had fruits only at seasons, also all other foods, but it is true that all these things were natural. I'm crazy today with the food. Look how much you are speaking about obesity..."

The socialist period is described as one in which women had good living standards, and could interact on an equal level with men. The feeling of nostalgia is also connected to the loss of a different gender regime, as Diana, near 67, doctor said: "the socialist law was very friendly to women. Officially, in everything there was equality with men. Today I can read in the newspaper: We don't want women for this job, or women only; we want women who are thirty and nice. It was completely forbidden at the time, it would be a scandal if someone used this language (...) we were satisfied with law. But we were not satisfied with patriarchy (...) "

Olimbia, 63 years old, ex-director of the bank, said: "That time? Not anymore! I remember polyester clothing laundry olive-oil Rogozhina or Vlora soap, weak without a day to rest, because Sunday was reserved for action to clean the territory behind the house, or to work voluntary in agriculture. There is no car to do the job, and I walked for km to inspect the finances of the cooperatives in all villages of the region. Saturday afternoon was the cleaning day of the house, so can you imagine what my life has been at that time? (...)"

Fuat, 72 years, said "Yesterday we ve a bad life, but we thought more positive for each-other. Today, we live more better, but thinking more bad to each-other."

Dimitri, 52 years old, theater director, said "... Volunteer work was the base of active life of the children. I remember the case of traffic controller by the pioneers, the guards of honor, commemorative celebrations occasions. The best pupils helped those weak to better learning. He also said that need to respect the past memories, monuments, works of art, which are parts of the Albanian history, such as "The pyramid" in the center of Tirana, specific objects just like bunkers, and so on, as real story of our parents and ours too, as well as basic cognition for the new generation. The tradition is always connected with national identity, so it's strongly important and crucial for a country and its people."

Karafil, near 57 years, ex-military remembered the dollar-shop in Vlora city, where some people that had relatives abroad Albania changed the money, or bought "Western things"(watches, tv-s, magneto phones, radios, refrigerators, sun glasses ect). These people were different from the others in clothing and lifestyle. Now, we are freely owners, some with big problems on documents, but there is the possibility for all of us to be somebody in business too."

Terminology of the today's Albanian reality brings changes in the perception for classes. It is not speaking for the "working class", nobody use the terms as "bej, bejlere", "aga, agallare", "shok, shoqe". These terms have been replaced with terms businessman, boss, sir, madam. Albanian cinematography is not producing films for children. Now, symbolic education, even coming from the past, is realized through films as "Beni walks alone", "Rebellion in the palace", "A general caught slave,"Our friend Tili", etc.. These are productions dominated by strong doses of artificial ideological as well as by overlaps of parental feelings where the first conceived parent was the Party of Labor of Albania. Highlighted in interviews was the case which turned than into humor because of its emptiness placed in the mouth of a child, in the film "In our house", produced in 1987. The mother said to her son who did a mistake living the school: "Miri, why do you do these things? To whom you look like? What are you? "The child replies:" I am yours. I belong to the state." And in another sequence when the teacher wanted to criticized him in the classroom (typically collective punishment) one girl from the class said:" ...these behaviors serve only to bourgeois, to revisionist..." While the boy very irritated interrupted said: "I'm not a bourgeoisie, I'm not a revisionist. I' $m$ Albanian.", and leave the class away. It's worthy to notice the messages about the unity, regardless of age, which value and encourage the involvement of children in all sectors of society. Their education has the collective control responsibility. Alma, teacher in elementary school comment a film: "Taulant requires a sister" as-the tendency of perception start for birth control in family in contrary with ideology trends of the time for increasing population policies. Now in the base of the films are standing migration histories, criminality, traffics, familiar trauma and human behavior alienation. 


\section{Conclusions}

In the 100 anniversary (2012) of Albanian Independence Day, the term "memory" was one of the more discussed especially in a historical background, although the analysis are connected with the people human behavior in general and the most prestigious personalities in special moments. Not always the people understand the term memory. They immediately tend to remember the past and then prejudice the future. The academics know better that Bulgaria was different from Czechoslovakia, Romania from Poland, Albania from Yugoslavia, and all were different from the imperial center, the Soviet Union. These differences have become even more salient and deeper after the collapse of communism and the dismantling of the Soviet empire. Eastern and Central Europe today presents a colorful mosaic of countries different in economic standards, political arrangements, cultural values, lifestyles, mentalities, etc. Why this is so? Keeping in mind that, for decades and in some cases for half a century, these countries were subjected to the powerful unifying mold of Soviet-type institutions, organizational arrangements, and indoctrinating pressure imposed by the imperial power, what are the causes of such diversity? And after the collapse of the empire, they have fallen under the new unifying forces: one broader, operating on a world scale and known as globalization, which entered forcefully through the open gates of "open societies"; and another narrower, operating on the regional scale and labeled European integration, which became the common aspiration and political intention of most post-communist countries. In spite of all these influences, they remain different and preserve unique identities. Why?

The economic changes, the change of mentalities for classes, relations with foreigners, the contradictions between the old and the young, produce internal tensions, but does not erase fundamental report with the community, the country, which develops its role of identification. To be well oriented it's necessary a "sacrifice of imagination" that helps us pass the traditional theoretical and methodological directions. Traditional sociological categories evaluated not enough appropriate to explain the new social dynamics, such as behavior and attitudes of younger generations in a territory. So to make concepts worthy, must consistently return by the treatments of social and psychological dimensions of human behavior, which bring to us the identity issues in the certain areas. The key moment to success as my professor Liugi Zà says is: knowing how to transmit to the people the culture of development. It's important to remember that one of the pillars of sustain development is the evaluation of feasible energy by activating the general awareness and promotion to interested population, as well as to the technicians.

\section{References}

Fukuyama,F.(1992):The end of the history and the last man. New York: Free Press.

Human Development Report, Albania 2002

Magri,L.(1991): "The European Left between Crisis and Re foundation" New Left Review,189, ,pp.5-18

Skëndi,S.(1987):Balkan Studies, New York, Columbia University Press,4.

Sutton, D.(1998): Memories Cast in Stone: The Relevance of the Past in Everyday Life. Oxford: Berg.

Sztompka, Pitor (1990): "Conceptual Frameworks in Comparative Inquiry", in Globalization, Knowledge and Society, Albrow, M. and King, E. (eds.),London, Sage, 47-60.

Todorova, M., Nikolaeva, and Zsuzsa Gille.(2010): Post-Communist Nostalgia. New York: Berghahn Books.

Watson, R.( 1994): "Memory, History, and Opposition under State Socialism: An Introduction." in R. Watson (ed.) Memory, History, and Opposition under State Socialism. Santa Fe: School of American Research Press.

Bonfiglioli, Chiara, (2011): in Former East, Former West: post-Socialist Nostalgia and Feminist Genealogies in Today's Europe, www.formerwest.org. 